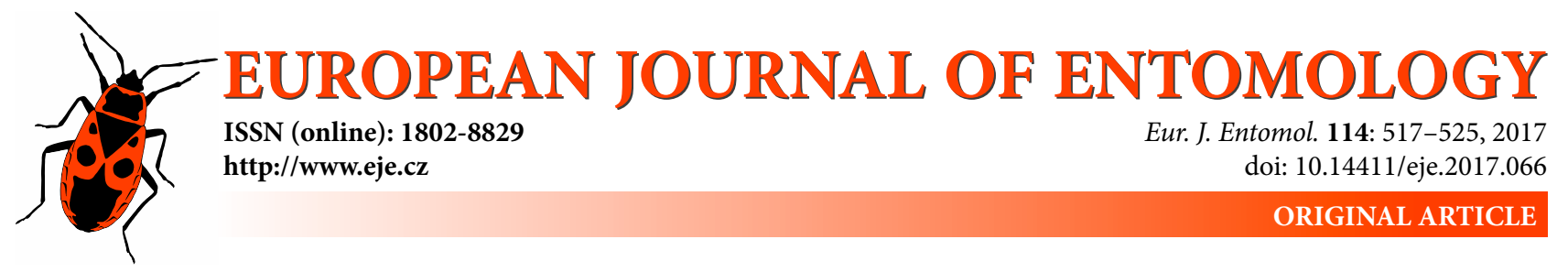

\title{
The year-round phenology of the migratory Red Admiral Vanessa atalanta (Lepidoptera: Nymphalidae) in a Mediterranean area in southern Spain
}

\author{
MARIANO CUADRADO \\ Departamento Técnico, ZooBotánico de Jerez, Madreselva s/n, E-11408 Jerez de la Frontera (Cádiz), Spain; \\ e-mail: mc.macuagu@gmail.com
}

Key words. Lepidoptera, Nymphalidae, Vanessa atalanta, migratory butterfly, phenology, winter reproduction, Mediterranean area, Spain

\begin{abstract}
Many studies report the migratory status of Vanessa atalanta in the Palearctic. Available evidence indicates that this species migrates north in spring to reproduce and south in autumn to reproduce in the Mediterranean area. However, little is known about the year-round phenology and their overwintering in southern regions. Here, I present data on the year-round phenology of adult $V$. atalanta recorded during a three year period (2014-2016) at 5 lowland sites $(<80 \mathrm{~m}$ a.s.I.) near the coast close to Cádiz (southern Spain). Overall, a total of 826 imagoes were recorded along $1499.3 \mathrm{~km}$ of Butterfly Monitoring Scheme (BMS) transects. Abundance was 0.55 butterflies $/ \mathrm{km}$ (data for all sites and years pooled) and varied greatly among sites and years. Coinciding with the migratory status, imagoes were recorded from September to June each year and the year-round abundance showed a typical bimodal distribution with two peaks of abundance, one in late winter (February) and another in autumn (November). Abundance was higher in spring $(0.87$ butterflies $/ \mathrm{km})$ than in autumn $(0.60$ butterflies $/ \mathrm{km})$. The emergence of a local generation in late winter was also recorded. My results agree with the migratory phenology of this species in the Palearctic and support the year round phenology data reported by Stefanescu (2001).
\end{abstract}

\section{INTRODUCTION}

Large numbers of many species of butterflies undertake seasonal movements each year, which are considered to be true migrations. Unlike the two-way migrations often considered to be typical of vertebrates, individual insects do not make a round-trip that brings them back to the area from which they departed. Instead, individuals of different generations take part in a multi-generational migratory movement (i.e. the offspring of a generation continues the migration trip for breeding purposes or to reach their wintering sites, e.g., Williams, 1930, 1957; Holland et al., 2006; Chapman \& Drake, 2010).

Among butterflies, the Monarch butterfly (Danaus plexippus) and several species of the family Nymphalidae are known to undertake large distance migratory movements towards the north in spring and the south in autumn, both in North America (United States of America and Canada) and Europe (e.g. Abbot, 1951; Urquhart \& Urquhart, 1977; Opler \& Krizek, 1984; Stefanescu, 2001; Holland et al., 2006; Dingle \& Drake, 2007; Stefanescu et al., 2007; Chapman \& Drake, 2010; Bitzer, 2016). For Vanessa car$d u i$, a number of interesting field studies provide new insights into the long distance migration between Africa and Europe and provide evidence of breeding and mass emer- gence in the Maghreb and sub-Saharan region prior to the spring migration north (Talavera \& Vila, 2016; Stefanescu et al., 2017) and of a migration south in autumn across the Sahara based on the composition of stable hydrogen isotopes in their wings (Stefanescu et al., 2016).

The Red Admiral, Vanessa atalanta, is a well-known migrant species in the United States (Opler \& Krizek, 1984; Bitzer, 2016) and Europe (Yela, 1984; Benvenuti et al., 1996; Stefanescu, 2001; Mikkola, 2003). In the Palearctic, this species migrates between the Mediterranean area and Scandinavia, north during spring to reproduce and south in autumn to overwinter (Mikkola, 2003; Brattström et al., 2008; Lundmark, 2010; Bitzer, 2016). Evidence for the northward migratory movement of Red Admirals is reported in many countries including Italy, Spain, Great Britain and Scandinavia (see Brattström et al., 2008 and references therein). Evidence of a southern migration is reported in Scandinavia (see Brattström et al., 2008 and references therein; Hansen, 2011), central Europe (e.g. Marco Thoma, pers. comm.; Roer, 1991), Italy (Benvenuti et al., 1996) and Spain (Stefanescu, 2001). In addition, some field studies report the direction in which most individuals fly during active migration in open areas (Benvenuti et al., 1996; see Bitzer, 2016 for a similar study in North America). 
While these studies examine the migratory status of Red Admirals in the Palearctic, little is known about the yearround phenology of this species in southern sites around the Mediterranean Basin (but see Stefanescu, 2001). Available evidence indicates that Vanessa atalanta reproduces during autumn and overwinters (either as an imago or immatures) in the Mediterranean area (e.g. Stefanescu, 2001; Mikkola, 2003; Brattström et al., 2008 and references therein; Lundmark, 2010). Stefanescu (2001) provides clear year-round phenology data for Vanessa atalanta at several lowland sites in Catalonia (NE Spain). This author reports the arrival of northern migrants in autumn, the reproduction of the species in winter and the migration of newly emerged imagoes to northern latitudes in spring. Here, I analyze the year-round phenology of Red Admiral imagoes counted at several lowland sites close to Cádiz (southern Spain) during a 3 year period. The aims of this study are as follows: (1) to determine the year-round phenology of imagoes in the area, (2) based on the seasonal abundance of imagoes and determine the dates when migration might occur and (3) compare the abundance of butterflies by year and site.

According to the year-round migratory pattern suggested above, two peaks of abundance (coinciding with the northward migration in spring and southward migration in autumn) should occur. In addition, a similar pattern is expected year after year in winter at different local sites within the same area. The location of the study area, at the southern tip of Western Europe close to N Africa, is important for the understanding of the migratory strategy of this and other species of butterflies. To my knowledge, this is the first time that these aspects have been studied at a Mediterranean site in southern Spain.

\section{MATERIALS AND METHODS}

\section{The species}

In the Palearctic, Vanessa atalanta migrates each year from central and northern Europe to overwinter in the Mediterranean area (S Europe and $\mathrm{N}$ Africa, see introduction for references). Stefanescu (2001) reports that migrant Vanessa atalanta arrive in October and early November and reproduce when there is the greatest availability of Urtica dioica, its principal host plant in the study area. A new generation emerges late in winter that migrates northward to reproduce. This author also suggests that this species might migrate at high altitudes as this species occurs at high altitudes within the Mediterranean area during spring and summer. The reproductive behaviour of Vanessa atalanta imagoes is very conspicuous because males are territorial and defend certain patches against other intruding males while systematically courting females. Reproductive males exhibit a characteristic behaviour called "hill-topping" (cf. Bitzer, 1995; Bitzer \& Shaw, 1979; Stefanescu, 2001) while defending such patches. In addition, the larvae of this species are easily recognizable by their habit of wrapping themselves in nettle leaves (Stefanescu, 2001).

\section{Butterfly counts}

Standard transect counts (Butterfly Monitoring Scheme, van Swaay et al., 2012) were used to record adult abundance. The transect method used in the BMS was used to record the number of butterflies seen by the observer in a volume of space $(5 \mathrm{~m}$ in width or $2.5 \mathrm{~m}$ on both sides; $5 \mathrm{~m}$ in height and $5 \mathrm{~m}$ in front of the observer) while walking slowly along the transect. The local time, ambient temperature, cloud cover (on a scale of 0 to 8 ) and wind speed (using $0-5$ on the Beaufort scale) were noted first at the beginning and then at the end of the transect (cf. Van Swaay et al., 2012). Counts were made between 10:00 and 19:00 local time on days with no rain and an ambient temperature $>13^{\circ} \mathrm{C}$. For this study, it was not necessary to capture any specimens. When necessary, $10 \times 40$ Zeiss binoculars were used to identify individual butterflies at a distance.

\section{Study sites}

The year-round BMS butterfly counts were carried out at 5 study plots located around Cádiz Bay (Cádiz, southern Spain). All were located at low altitudes $(<80 \mathrm{~m}$ a.s.l., distance between sites $<25 \mathrm{~km}$ ) near the coast of the Atlantic Ocean (Fig. 1). The climate in the area is typically Mediterranean with hot summers and mild winters. Rainfall during the winter and summer is extremely low. However, due to the low altitude and the proximity to the sea both winter and summer temperatures are less extreme than is typical for this climate. Technically, the climate is defined as "Mediterráneo submarítimo" (or sea-influenced Mediterranean climate, cf. Font Tullot, 1983).

At each study plot, transects $(570 \mathrm{~m}-2.6 \mathrm{~km}$ in distance) were established that passed through sites where this butterfly occurred. Following the BMS methodology, each transect was divided into $2-8$ sections $(200 \mathrm{~m}-800 \mathrm{~m}$ each). The characteristics of the plots and the period over which the field work was carried out were as follows (Fig. 1):

1. Jerez (Jerez de la Frontera, Cádiz, 36.689009, -6.150112). This study area was located in the gardens of ZooBotánico Jerez, a zoological park ( 6.5 ha in size) located in the west of the city of Jerez. The whole area was covered by dense vegetation composed of more than 400 species of plants (including trees, palms and bushes). Some trees were remarkably old ( $>25 \mathrm{~m}$ tall and $>150$ years old). The animal enclosures were surrounded by



Fig. 1. Maps showing the locations of the study areas where BMS butterfly counts were carried out. Study plots were located in Cádiz (S Spain) at Jerez (site A), San Fernando (site B - Punta del Boquerón, C - Jardín Botánico de San Fernando, D - Camposoto) and El Marquesado (E - Huerto Animado). 
trees, bushes and herbaceous plants where the butterflies were recorded. The whole area was surrounded by roads and buildings. To perform the BMS censuses, a $2 \mathrm{~km}$ transect was established and divided into 8 sections ( $200 \mathrm{~m}$ to $350 \mathrm{~m}$ each). Field work was carried out on 1-7 days per week. Routine butterfly counts started in 2011. From 2011 to 2013, the whole area was searched for butterflies once a day following different daily routines during which there were no restrictions on either transect width or maximum height. Standard BMS censuses (see above), were carried out from January 2014 to December 2016. The total distance covered in the BMS censuses was $954 \mathrm{~km}$ (290 in 2014, 310 in 2915 and 354 in 2016).

2. Punta del Boquerón (Parque Natural Bahía de Cádiz, 36.407491, -6.218390, San Fernando, Cádiz). This study area is a nature reserve located on the sea shore, $4 \mathrm{~km}$ south of the city of San Fernando. The study plot was a sandy spit totally surrounded by water (the Atlantic Ocean and the marsh area around "Caño Sancti Petri"). There are no roads or buildings in this area. The vegetation in the dune area is composed of shrubs of Retama monosperma (L.) Boiss. and typical sandy soil herbaceous plants (e.g. Malcolmia littorea L. R.Br., Echium gaditanum Boiss., Anthemis maritima L., Lotus creticus L.). The vegetation in the marsh area is composed of salt-adapted plants (e.g. Limoniastrum monopetalum L. Boiss., Arthrocnemum macrostachyum Moric. Moris, Inula crithmoides L., Suaeda vera Forssk. ex J.F. Gmel, Limonium algarvense Erben, Sarcocornia perennis Mill. A.J. Scott). The transect (2.6 km in length) was linear and divided into $6(300-800 \mathrm{~m})$ sections that extended in a NW-SE direction, parallel to the seashore. BMS censuses were carried out at least twice a month, from June 2014 to December 2016. The total distance covered in the BMS censuses was $309.4 \mathrm{~km}$ (23.4 in 2014, 88.4 $\mathrm{km}$ in 2015 and 197.6 in 2016).

3. Jardín Botánico de San Fernando (San Fernando, Cádiz, $36.472522,-6.201534)$. This study area is a typical botanical garden (1.2 ha in size) situated in the western part of the city of San Fernando. The vegetation is composed of large trees, bushes and herbaceous plants distributed in a mosaic-like fashion (i.e., plants were arranged in a geometric pattern). The entire area is surrounded by roads and buildings. To carry out the BMS censuses, a $0.97 \mathrm{~km}$ transect was established and divided into $6 \mathrm{sec}-$ tions (between 100 and $200 \mathrm{~m}$ each). BMS censuses were carried out at least once a month from July 2014 to December 2016. The total distance covered in the BMS censuses was $102.2 \mathrm{~km}(9.3$ in 2014, 26.5 in 2015 and 66.4 in 2016).

4. Camposoto (San Fernando, Cádiz, 36.441724, -6.2265352). This study plot ( 2.2 ha) is a rural track named "Sendero Salina Tres Amigos" in Parque Natural Bahía de Cádiz, $3 \mathrm{~km}$ south of the city of San Fernando. The track was located on the border of a large area of marsh. The vegetation in the area was characterized by bushes of Retama monosperma, isolated large trees (mostly Eucalyptus spp.) and exotic species of bushes, such as, Myoporum spp. G. Forst., Opuntia dillenii (Ker Gawl.) Haw., and Galenia secunda (L.f.) Sond. etc. The transect was linear (length $=0.72 \mathrm{~km}$ ) and divided into 4 sections (between 130 and 230 $\mathrm{m}$ each). Field work was carried out at least once a week from November 2015 to December 2016. The total distance covered in the BMS censuses was $109.3 \mathrm{~km}$ (10 in 2015 and 99.3 in 2016).

5. Huerto-Animado (El Marquesado, Cádiz, 36.443999, $-6.121109)$. This is a low-intensity organically cultivated area composed of fruiting trees and orchards combined with seasonal vegetables in a typical heterogeneous mosaic-like landscape. The density of buildings in this area is very low. The study plot (1.7 ha in size) included a small area of organically produced seasonal vegetables (tomatoes, beans, potatoes, cucumbers, watermelons, etc.) and isolated fruiting trees (Prunus dulcis (Mill.) D.A. Webb, Ficus carica L., Olea europaea L. etc.). The transect (length = $0.57 \mathrm{~km}$ ) was divided into 4 sections that passed through different crops in the area. Field work was carried out 1-4 times per month from July 2014 to December 2015. There was no field work in 2016 due to a change in the plot use decided by the owner. The total distance covered in the BMS censuses was $24.4 \mathrm{~km}(9.5$ in 2014 and 14.9 in 2015).

\section{Data analysis}

For each site, the numbers of butterflies recorded during BMS censuses and the distances walked per month were pooled. Imagoes recorded during field work included both males defending territories (with hilltopping behaviour, see above) and imagoes of both sexes moving and feeding among flowers. An abundance index based on the number of butterflies recorded per kilometer and month was then calculated (Appendix 1). The total distance walked in BMS censuses was $1499.3 \mathrm{~km}$ : 954 at Jerez, 309.4 at Punta del Boquerón, 102.2 at Jardín Botánico de San Fernando, 109.3 at Camposoto and 24.4 at Huerto-Animado.

Table 1. Abundance index in terms of the number of Vanessa atalanta/km recorded from 2014 to 2016 at the different sites studied. Two periods when the abundance was recorded were spring (from 1 January to 31 May) and autumn (from 1 September to 31 December). BMS methodology was used to count the butterflies at all sites.

\begin{tabular}{|c|c|c|c|c|c|c|c|}
\hline & \multirow{2}{*}{ Year } & \multicolumn{3}{|c|}{ Spring } & \multicolumn{3}{|c|}{ Autumn } \\
\hline & & $\mathrm{km}$ & $\mathrm{N}$ & Abundance & $\mathrm{km}$ & $\mathrm{N}$ & Abundance \\
\hline Jerez & 2014 & 140.0 & 142 & 1.01 & 90.0 & 117 & 1.30 \\
\hline Jerez & 2015 & 110.0 & 82 & 0.74 & 118.0 & 53 & 0.44 \\
\hline Jerez & 2016 & 144.0 & 203 & 1.40 & 128.0 & 82 & 0.64 \\
\hline Punta del Boquerón & 2014 & - & - & - & 10.4 & 1 & 0.09 \\
\hline Punta del Boquerón & 2015 & 23.4 & 4 & 0.17 & 44.2 & 4 & 0.09 \\
\hline Punta del Boquerón & 2016 & 62.4 & 8 & 0.12 & 80.6 & 22 & 0.27 \\
\hline Jardín Botánico de SF & 2014 & - & - & - & 5.5 & 1 & 0.18 \\
\hline Jardín Botánico de SF & 2015 & 7.4 & 3 & 0.40 & 12.4 & 1 & 0.08 \\
\hline Jardín Botánico de SF & 2016 & 23.1 & 10 & 0.43 & 23.1 & 11 & 0.47 \\
\hline Camposoto & 2015 & - & - & - & 10.0 & 8 & 0.80 \\
\hline Camposoto & 2016 & 41.7 & 26 & 0.62 & 33.2 & 17 & 0.51 \\
\hline Huerto Animado & 2014 & - & - & - & 3.8 & 8 & 2.10 \\
\hline Huerto Animado & 2015 & 3.1 & 7 & 2.25 & 6.8 & 2 & 0.29 \\
\hline \multirow[t]{3}{*}{ All sites } & 2014 & 140.0 & 142 & 1.01 & 109.7 & 127 & 1.15 \\
\hline & 2015 & 143.9 & 96 & 0.66 & 191.4 & 68 & 0.35 \\
\hline & 2016 & 271.2 & 247 & 0.91 & 241.8 & 132 & 0.54 \\
\hline Data pooled & & 555.1 & 485 & 0.87 & 542.9 & 327 & 0.60 \\
\hline
\end{tabular}




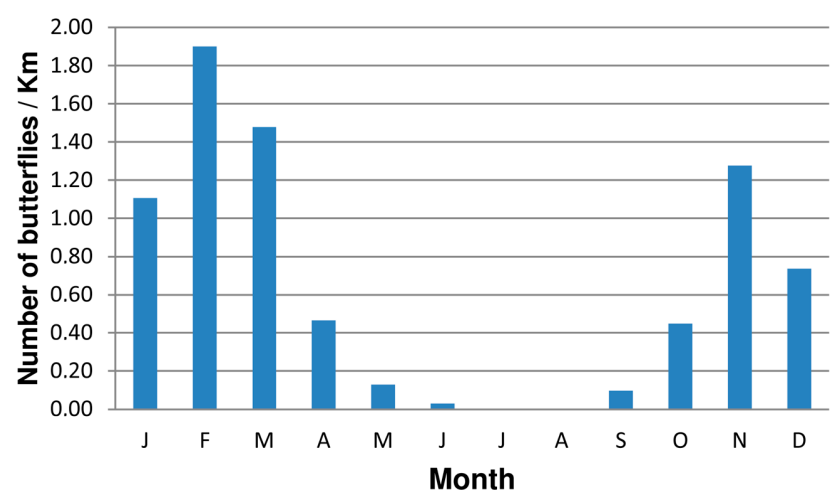

Fig. 2. Monthly distribution of the abundance of Vanessa atalanta recorded during field work. Abundance is the number of butterflies recorded per km and month based on the BMS (Butterfly Monitoring Scheme, cf. Van Swaay et al., 2012). Data for five study sites (see methods) and three years (2014-2016) were pooled for the calculations. Overall, the total number of butterflies recorded was 826 along $1499.3 \mathrm{~km}$ (or 0.55 butterflies $/ \mathrm{km}$ ).

\section{RESULTS}

\section{Year-round phenology}

A total of 826 Red Admiral imagoes (or 0.51 butterflies/ $\mathrm{km}$ ) were recorded during the BMS censuses (see Table 1 , data for all years and sites pooled). The year-round abundance based on the number of butterflies recorded (Fig. 2) has a typical bimodal distribution with two welldefined periods when the species was more abundant: one in late winter (up to February) and another in autumn (up to November). Thus, according to their migratory status, Red Admirals arrived to the area in September-October reaching their maximum abundance in November. The numbers decreased greatly during the mid-winter months (December and January) and reached a new maximum in late winter (February) after the emergence of a new generation. From March onwards, the number of Red Admirals steadily decreased, probably due to them migrating north,

\section{Jerez $(\mathbf{N}=693)$}

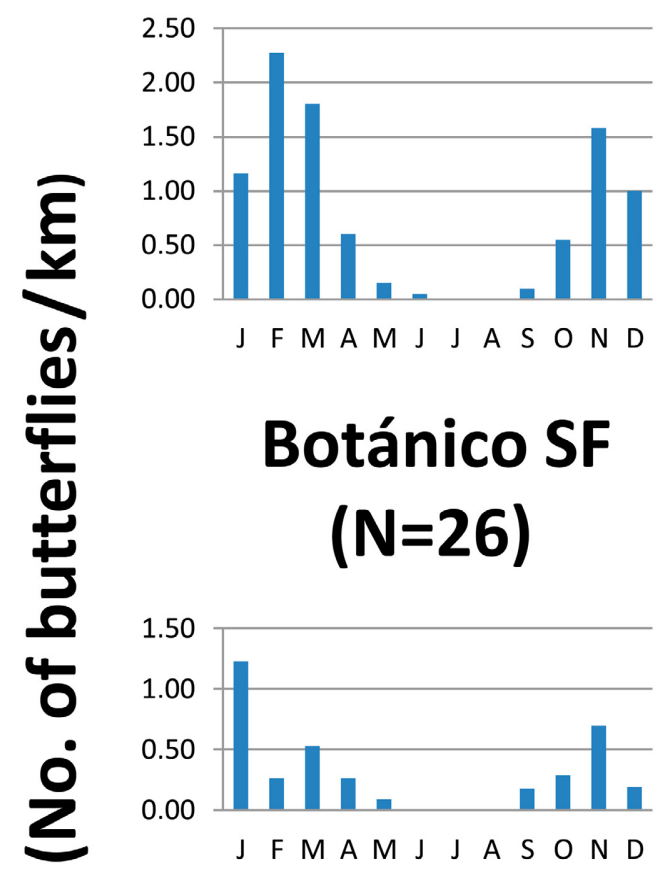

P. Boquerón $(\mathrm{N}=39)$

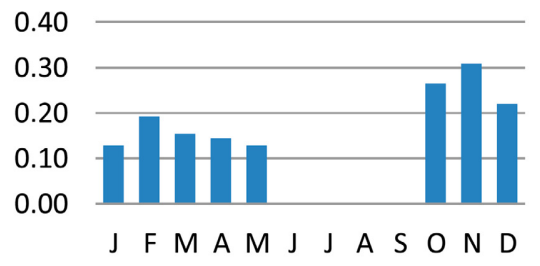

Camposoto $(\mathrm{N}=51)$

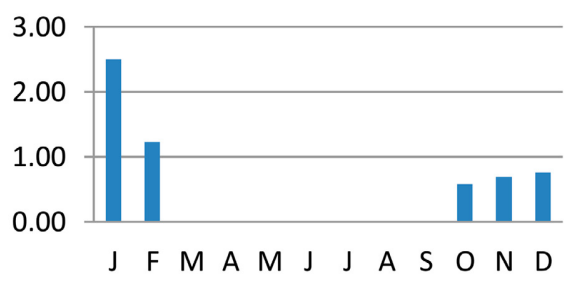

Huerto Animado

$(\mathrm{N}=17)$

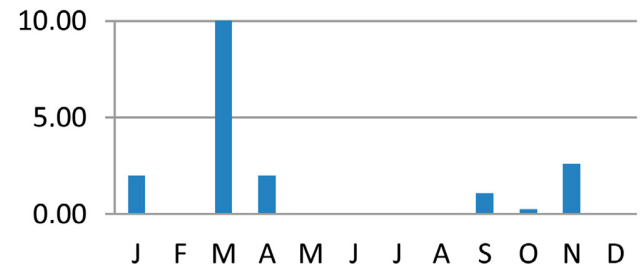

Fig. 3. Monthly distribution of the abundance of Vanessa atalanta recorded at the Jerez site from 2011 to 2016 . Abundance is the percentage of the yearly total of individuals that was recorded in each month. The total number of butterflies recorded per year was included. The BMS procedure for counting butterflies was used between 2014 and 2016. From 2011 to 2013, the whole area was searched for butterflies with no width or height restrictions on the dimensions of the transect (see Methods). 

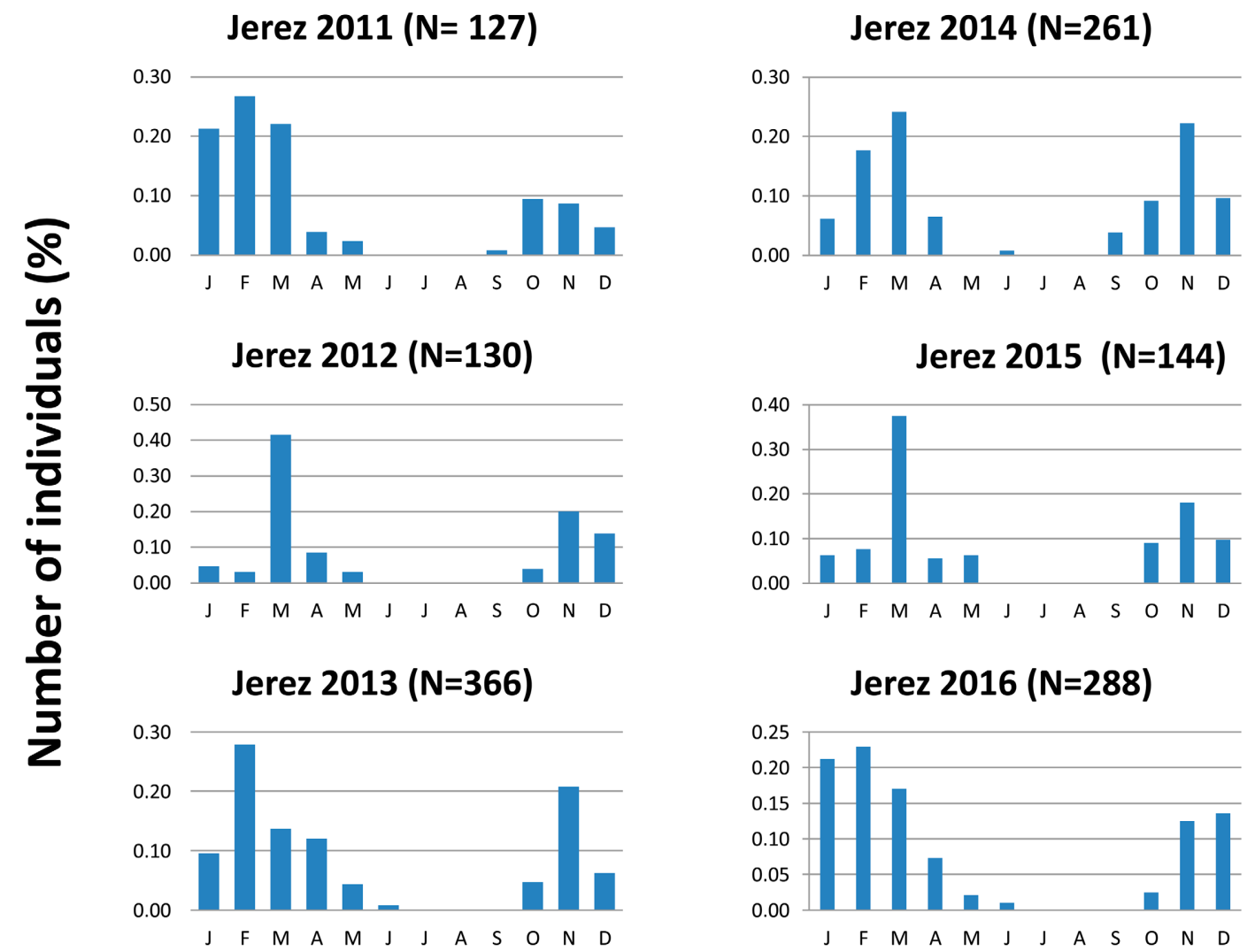

Fig. 4. Monthly distribution of the abundance of Vanessa atalanta recorded during field work at each site. Abundance is the number of butterflies recorded per km and month according to the BMS (Butterfly Monitoring Scheme, cf. Van Swaay et al., 2012). At each site, data for three years (2014-2016) were pooled for the calculations.

with none present during the summer months (July and August, Fig. 2).

The residence period of Red Admirals was accurately recorded at the Jerez site each year between 2011 and 2016 (Fig. 3). In Jerez, Red Admirals were recorded from 20.ix.2011 to 8.vi.2012, from 15.ix.2012 to 19.vi.2013, from 7.x.2013 to 27.vi.2014, from 22.ix.2014 to 28.v.2015, from 13.ix.2015 to 20.vi.2016 and finally, from 29.ix to 31.xii.2016. Remarkably, this species showed the same bimodal distribution year after year at the Jerez site and was absent during the summer months (July and August) with one exception: one imago was recorded on 24.vii.2014, but not along one of the BMS transects (Fig. 3).

\section{Variation in abundance among sites}

The number of butterflies and their abundance index varied greatly from site to site: 693 at Jerez (or 0.73 butterflies/km), 39 at Punta del Boquerón (or 0.13), 17 at Huerto-Animado (or 0.70), 26 at Jardín Botánico de San Fernando (or 0.25) and 51 at Camposoto (or 0.47). However, remarkably the year-round distribution was very similar at all the sites studied, with higher numbers in spring than in the autumn and the complete absence of this species in summer (Fig. 4).

\section{Variation in the abundance within and between years}

Here the abundance of Red Admirals in two different periods was compared as follows: spring (data from 1 Janu- ary to 30 June pooled) and autumn (data from 1 September to 31 December pooled). The abundance of Red Admirals varied depending on the year and site (Table 1). As expected, the abundance of Red Admirals was higher in spring $(0.87$ butterflies $/ \mathrm{km})$ than in autumn $(0.60$ butterflies $/ \mathrm{km})$. Similarly, the abundance of butterflies was higher in late winter (after the emergence of a new winter generation) than in autumn (the arrival of migrant Red Admirals from northern latitudes (Fig. 2). In addition, the abundance was also higher in 2014 than in 2015 or 2016 (Table 1).

\section{DISCUSSION}

\section{Year-round phenology of migrant Red Admirals}

The year-round phenology of Red Admirals recorded in this study agrees with the migratory status (with northern movement to reproduce in spring and southern movements in autumn to reproduce in winter) indicated by many studies carried out in the Palearctic area (e.g. Stefanescu, 2001; Mikkola, 2003; Brattström et al., 2008; Lundmark, 2010; see also Bitzer, 2016 and references therein for a similar pattern recorded in the Nearctic). In the study area, the peaks of abundance recorded coincide with the progressive arrival of migrant butterflies in autumn (from September to November), a lower number of imagoes in the mid-winter months (December-January) and a new peak in abundance due to the emergence of a new generation in late winter (February-March). Furthermore, the number of imagoes steadily decreased from March to June indicating 

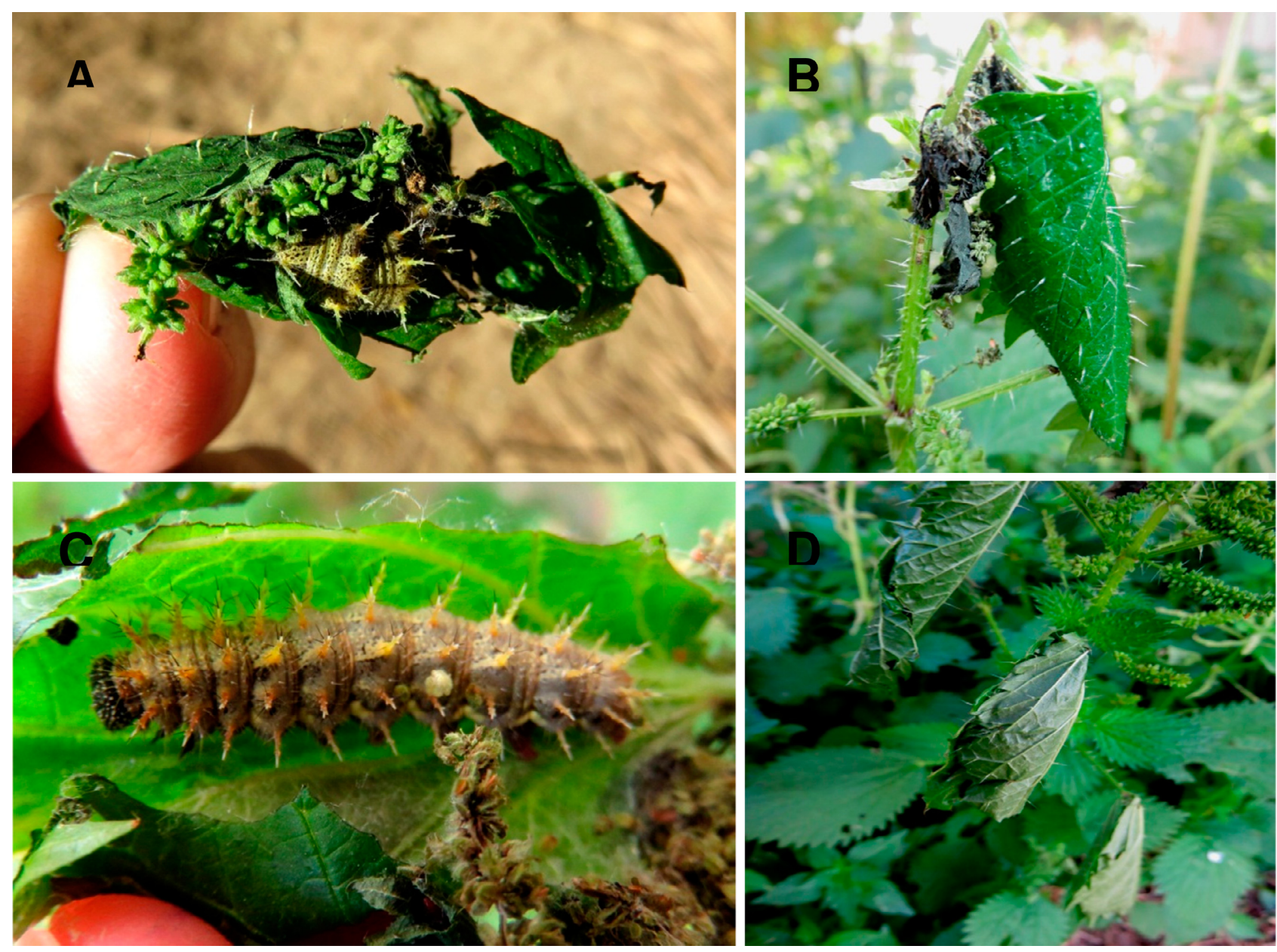

Fig. 5. Photographs of the immature stages of the Red Admirals at the Jerez site taken in late winter 2017. Photographs were taken on 8 March 2017 (A, D), 19 March 2017 (B) and 4 April 2017 (C).

that Red Admirals abandoned the area and migrated north soon after emergence and were absent during the summer months (July and August). This year-round phenology is remarkably similar to that reported by Stefanescu (2001) at another Mediterranean site in north-east Spain. In fact, this seems to be the general trend at low latitudes as Red admiral imagoes are absent, or very rare, in summer (see also Gargallo Macías, 2014) but very common in autumn and winter (see also Pollard \& Yates, 1993; Stefanescu, 2001; Mikkola, 2003; Brattström et al., 2008; Cuadrado, 2013; Fernández-Haeger et al., 2014; Fox et al., 2015; this study).

There is other evidence that supports the migratory status of this species in this area. Firstly, $V$. atalanta is a bivoltine species (cf. Corbet, 2002, see also Yela, 1984; González López, 2008) as indicated by the bimodal pattern in the abundance recorded at many sites (this study) whereas other resident species such as Iphiclides podalirius L., Pieris spp L., Pararge aegeria L. or Papilio machaon L. are multivoltine and complete up to three or more generations a year (Cuadrado, 2016). Interestingly, species classified as residents are more abundant during the favourable season in the area (May and June), a pattern remarkably different to that recorded for Red Admirals in this study. And secondly, environmental conditions during summer (hot temperatures and no rain) cause herbaceous vegeta- tion to wither (also known as "agostamiento", cf. Molina Rodríguez, 1988, Stefanescu, 2001; Obregón \& Sánchez 2015; pers. observ. ) including the host plant of Red Admiral larvae (Urtica sp.). Due to the absence of host plants at this time, Red Admirals recorded in autumn are definitely migrants and not of local origin.

Although our data indicate that Vanessa atalanta is bivoltine (this study, see references above) there is a possibility that individuals of this species produce a succession of 3-4 generations year-round within their distribution in the W Palearctic region (C. Stefanescu, pers. com). Thus, each generation might be produced in a different region in a given period depending on environmental conditions. In addition, some spatio-temporal overlap could occur between generations and sites, making the whole cycle quite complex (C. Stefanescu, pers. com.). While this is a plausible idea, more data are needed to clarify this point.

Dingle \& Drake (2007: 114) define the requirements that an animal movement should meet in order to be considered true migration. According to their criteria, migration must be: (1) a notably persistent, undistracted and straightened out (or directional) movement, (2) involve a relocation of the animals that is on a much greater scale and over a much longer duration than during their normal daily activities; (3) a seasonal to-and-fro movement of populations be- 
tween regions where conditions are alternately favourable or unfavourable (including one region in which breeding occurs); and (4) movements leading to redistribution of a spatially extended population. The active migration of Red Admirals (condition 1) has been reported at several European sites (Reichholf, 1978; Roer, 1991; Benvenuti et al., 1996; Stefanescu, 2001; Brattström et al., 2010; Marco Thoma, pers. comm.). In addition, these movements are of a continental scale and recorded in both Europe and North America (condition 2, see references above). Furthermore, the year-round phenology is highly predictable and was recorded year after year in the same area in this study (see Results, condition 3) and finally, the arrival and redistribution of Red Admirals at different overwintering sites in this study occurred simultaneously at least in the areas studied (condition 4, this study, see also Mikkola, 2003).

\section{Reproduction of Red Admirals in autumn and winter}

Evidence of Red Admirals reproducing in the areas studied was remarkably clear. Reproductive behaviour in males (see above) was recorded soon after their arrival in September and continued throughout the winter until the end of April (unpubl. data). Males were consistently recorded defending sunny, west-oriented open areas by linear structures (such as fences, line of trees, see also Bitzer \& Shaw, 1979; Bitzer, 1995; Cuadrado, 2013; Myers et al., 2013) while searching for females. The defence of these patches occurs a few hours before sunset (see for instance Swansson \& Monge-Nájera, 2000 for a detailed analysis of the effect of climate on this behaviour). All males were systematically repelled whereas females elicited typical courtship (two specimens flying up-and-down in dipping flight near the ground, after which the female lands on the ground and the male runs up alongside her and attempts to mate, cf. Bitzer pers. comm). All these behaviours were recorded throughout the autumn and winter periods. However, copulations, egg-laying, larvae or pupae were never recorded during this three year study (2014-2016).

This situation however changed in the winter of 2017 at the Jerez site when several egg-laying females were recorded, which was not observed during the 2011-2016 period. More importantly, many larvae at different stages of development were recorded simultaneously in different patches in the study area (Fig. 5). As expected, all immatures fed for several weeks (between February and May 2017) on Urtica membranacea Poir, their host plant in the area. These findings indicate that this species reproduces both in autumn, coinciding with the arrival of autumn migrants, and the autumn generation in winter. The absence of immature stages during the field work period could be due to remarkably low numbers of larvae during these years, as is also reported by Stefanescu (2001) in some years at his study site.

While it was obvious that this species reproduced in winter at the sites studied, there is a possibility that some imagoes recorded after winter emergence come from a more southern population. Brattström et al. (2010) studied the migratory pattern of some European populations of Van- essa atalanta by analyzing the stable hydrogen isotopic ratio (dD) in butterfly wings. This analysis provides good clues of the origin of the imagoes (i.e., the geographical area where the larva developed). Interestingly, the authors compare isotope concentration in Red Admiral wings with those of non-migratory species in the area such as Pieris manni Mayer and Lasiommata megera L. The analysis of the data at a Mediterranean site (The Island of Capri, Italy) indicate that Red Admirals recorded in autumn came from northerly regions. The same analysis performed in spring indicate that this species reproduced in the Mediterranean area in winter (see also Stefanescu, 2001) but also, some butterflies probably came from a more southern region (maybe North Africa). As indicated by the 2017 records, Red Admiral imagoes recorded in the area in late winter and spring were probably mostly composed of individuals that emerged locally. However, there is a possibility that some imagoes came from a more southern region (see also Brättstom et al., 2010). In support of this idea, Red Admirals are known to migrate further south than the Iberian Peninsula in autumn and colonize (and breed) different areas in Morocco where some species of Urtica are available (C. Stefanescu, pers. comm). These migrants will certainly produce some offspring that will probably migrate northwards upon emergence in late winter or early spring. The use of isotope analyses in the future could clarify this point.

To conclude, my results accord with those of Bitzer (2016) who points out that Red Admirals occur mainly in gardens or low-intensity agriculture areas and are less abundant in natural areas (see Jerez and Punta del Boquerón results for comparisons). Considerable differences in the abundance of Red Admirals between sites depending on the year were also noted. A more detailed analysis comparing the abundance of Red Admirals by year and by site is not possible due to the low number of years in which their abundance was recorded.

ACKNOWLEDGEMENTS. I am grateful for the comments provided by R.J. Bitzer, M. Menz, C. Stefanescu and two anonymous referees on an early draft of this paper. R.J. Bitzer and D. Levey kindly checked the English. This study was carried out without any financial support.

\section{REFERENCES}

Аввот C.H. 1951: A quantitative study of the migration of the Painted Lady butterfly, Vanessa cardui L. - Ecology 32: 155171.

Benvenuti S., Dall'antonia P. \& Ioalè P. 1996: Directional preferences in the autumn migration of the Red Admiral (Vanessa atalanta). - Ethology 102: 177-186.

BITZER R.J. 1995: Territorial Behavior of the Red Admiral Butterfly, Vanessa atalanta (L.) (Lepidoptera: Nymphalidae). Thesis, Iowa State University, 227 pp.

Bitzer R.J. 2016: The Red Admiral and Painted Lady Research. URL: http://vanessa.ent.iastate.edu/ [last accessed 21 Jan. 2016].

Bitzer R.J. \& Shaw K.C. 1979: Territorial behavior of the Red Admiral, Vanessa atalanta (L.) (Lepidoptera: Nymphalidae). —J. Res. Lepid. 18: 36-49. 
Brattström O., KJellén N., Alerstam T. \& Åkesson S. 2008: Effects of wind and weather on red admiral (Vanessa atalanta) migration at a coastal site in southern Sweden. - Anim. Behav. 76: $335-344$

Brattström O., Bensch S., Wassenaar L.I., Hobson K.A. \& ÅKESSON S. 2010: Understanding the migration ecology of European red admirals Vanessa atalanta using stable hydrogen isotopes. - Ecography 33: 720-729.

Chapman J.W. \& DraKe V.A. 2010: Insect migration. In Breed M.D. \& Moore J. (eds): Encyclopedia of Animal Behavior. Vol. 2. Oxford Academic Press, Oxford, pp. 161-166.

CoRBET P.S. 2002: Stadia and growth ratios of Odonata: a review. - Int. J. Odonatol. 5: 45-73.

Cuadrado M. 2013: Fenología de mariposas diurnas comunes (Vanessa atalanta, Vanessa cardui, Iphiclides podalirius y Papilio machaon) en el ZooBotánico de Jerez. — Revta Soc. Gadit. Hist. Nat. 7: 15-21.

CuAdRado M. 2016: Número de generaciones (voltinismo) en varias especies de mariposas diurnas en una población de Jerez de la Frontera (Cádiz). — Revta Soc. Gadit. Hist. Nat. 10: 27-31.

Dingle H. \& Drake V.A. 2007: What is migration? - Bioscience 57: $113-121$.

Fernández Haeger J., Jordano Barbudo D. \& Obregón Romero R. 2014: Las mariposas del entorno de la laguna de Zoñar. In de la Cruz J (ed.): Humedales Cordobeses: 30 Años de Protección. Consejería de Medio Ambiente y Ordenación del Territorial. Junta de Andalucía, Sevilla, pp. 165-171.

Font Tullot I. 1983: Climatología de España y Portugal. Instituto Nacional de Meteorología, Madrid, 422 pp.

Fox R., Brereton T.M., Asher J., August T.A., Botham M.S., Bourn N.A.D., Cruickshanks K.L., Bulman C.R., Ellis S., Harrower C.A., Middlebrook I., Noble D.G., Powney G.D., Randle Z., Warren M.S. \& Roy D.B. 2015: The State of the UK's Butterflies 2015. Butterfly Conservation and the Centre for Ecology and Hydrology, Wareham, Dorset, $27 \mathrm{pp}$.

Gargallo Macías A.L. 2014: Distribución y fenología de mariposas diurnas comunes (Vanessa atalanta, Vanessa cardui, Iphiclides podalirius, $y$ Papilio machaon) en la provincia de Cádiz. Mmaster Thesis, Universidad de Cádiz.

GonzÁlez López F. 2008: Mariposas Diurnas del Parque Regional Sierra de Espuña. Dirección General del Medio Natural Consejería de Desarrollo Sostenible y Ordenación del Territorio, Murcia, $119 \mathrm{pp}$.

HANSEN M.D.D. 2001: Observations on migrating red admirals (Vanessa atalanta L.) in Denmark 1995-2000. - Flora Fauna 107: $1-5$.

Holland R.A., WiKelski M. \& Wilcove D.S. 2006: How and why do insects migrate? - Science 313: 794-796.

KenNedy J.S. 1985: Migration: Behavioral and ecological. In Rankin M.A. (ed.): Migration: Mechanisms and Adaptive Significance. Contributions in Marine Science 27 (suppl.). Marine Science Institute, University of Texas, Austin, pp. 5-26.

LundMARK C. 2010: Long-distance insect migration. - BioScience 60: 400 .

Mikкola K. 2003: The red admiral butterfly (Vanessa atalanta, Lepidoptera: Nymphalidae) is a true seasonal migrant: an evolutionary puzzle resolved? - Eur. J. Entomol. 100: 625-626.

Molina Rodríguez J.M. 1988: Faunística y dinámica espaciotemporal de los Ropalóceros de la Sierra Norte de Sevilla (Lepidoptera: Papilonidea et Hesperioidea). Ph.D. Thesis. University of Sevilla.
Myers P., Espinosa R., Parr C.S., Jones T., Hammond G.S. \& Dewey T.A. 2013: Vanessa atalanta. URL: http://animaldiversity.org/accounts/Vanessa_atalanta/ [last accessed 30 Jan. 2017].

Obregón R. \& SÁnchez J.M. 2015: Mariposas diurnas de Sierra Morena de Córdoba. Ayuntamiento de Córdoba, Córdoba, 81 pp.

Opler P.A. \& Krizek G.O. 1984: Butterflies East of the Great Plains. Johns Hopkins University Press, Baltimore, 322 pp.

Pollard E. \& Yates T.J. 1993: Monitoring Butterflies for Ecology and Conservation. The British Butterfly Monitoring Scheme. Chapman and Hall, London, 274 pp.

ReichHolf J. 1978: Zur raumlichen Struktur des Zugmusters der Wanderfluge von Admiral (Vanessa atalanta L.) und grossem Kohlweissling (Pieris brassicae L.) an der Adria. - Dt. Entomol. Z. 251: 191-194.

Roer H. 1991: On the direction of migration and flight capacity of the nymphalids Inachis io, Aglais urticae and Vanessa atalanta in the central European area after recapturing marked butterflies. - Entomol. Ber. 51: 179-182.

Stefanescu C. 2001: The nature of migration in the red admiral butterfly Vanessa atalanta: evidence from the population ecology in its southern range. - Ecol. Entomol. 26: 525-536.

Stefanescu C., Alarcon M. \& Avila A. 2007: Migration of the painted lady butterfly Vanessa cardui to north-eastern Spain is aided by African wind currents. - J. Anim. Ecol. 77: 888-898.

Stefanescu C., Soto D.X., Talavera G., Vila R. \& Hobson K.A. 2016: Long-distance autumn migration across the Sahara by painted lady butterflies: exploiting resources pulses in the tropical Savannah. — Biol. Lett. 12: 20160561, 4 pp.

Stefanescu C., Puig-Montserrat X., Samraoui B., Izquierdo R., Ubach A. \& Arrizabalaga A. 2017: Back to Africa: autumn migration of the painted lady butterfly Vanessa cardui is timed to coincide with an increase in resource availability. - Ecol. Entomol. 42: 737-747.

Swansson H.F. \& Monge-Nágera J. 2000: The effect of methodological limitations in the study of butterfly behavior and demography: a daily study of Vanessa atalanta (Lepidoptera: Nymphalidae) for 22 years. - Revta Biol. Trop. 48: 605-614.

TALAVERA G. \& VILA R. (in press): Discovery of mass migration and breeding of the painted lady butterfly Vanessa cardui in the Sub-Sahara: the Europe-Africa migration revisited. - Biol. J. Linn. Soc. doi: 10.1111/bij. 12873

URQUHART F.A. \& URQUHART N.R. 1977: Overwintering areas and migratory routes of the monarch butterfly (Danaus plexippus) in North America, with special reference to the western population. - Can. Entomol. 109: 1583-1589.

Van Swaty C.A.M., Brereton T., KirKLand P. \& Warren M.S. 2012: Manual for Butterfly Monitoring. Report VS2012.010, De Vlinderstichting/Dutch Butterfly Conservation, Butterfly Conservation UK y Butterfly Conservation Europe, Wageningen, $12 \mathrm{pp}$.

Williams C.B. 1930: The Migration of Butterflies. Oliver and Boyd, Edinburgh, 473 pp.

Williams C.B. 1957: Insect migration. - Annu. Rev. Entomol. 2: $163-180$.

Yela J. 1984: Ninfálidos y libiteidos de Trillo (Guadalajara). II Parte. - Shilap Revta Lepid. 12: 205-209.

Received May 8, 2017; revised and accepted November 6, 2017 Published online November 23, 2017 
Appendix 1. Monthly abundance of adults of Red Admiral (Vanessa atalanta) recorded at the study plots from 2014 to 2016 . Data per month was pooled for calculations. Abundance is the number of butterflies recorded per km and month according to the BMS (Butterfly Monitoring Scheme, cf. Van Swaay et al., 2012).

\begin{tabular}{|c|c|c|c|c|c|c|c|c|c|c|c|c|}
\hline \multirow{2}{*}{ Month } & \multicolumn{3}{|c|}{2014} & \multicolumn{3}{|c|}{2015} & \multicolumn{3}{|c|}{2016} & \multicolumn{3}{|c|}{ Total } \\
\hline & $\mathrm{km}$ & No. & Abundance & $\mathrm{km}$ & No. & Abundance & $\mathrm{km}$ & No. & Abundance & $\mathrm{km}$ & No. & Abundance \\
\hline \multicolumn{13}{|l|}{ JEREZ } \\
\hline January & 32 & 16 & 0.50 & 18 & 9 & 0.50 & 24 & 61 & 2.54 & 74 & 86 & 1.16 \\
\hline February & 18 & 46 & 2.56 & 12 & 11 & 0.92 & 24 & 66 & 2.75 & 54 & 123 & 2.28 \\
\hline March & 38 & 63 & 1.66 & 22 & 54 & 2.45 & 30 & 49 & 1.63 & 90 & 166 & 1.80 \\
\hline April & 24 & 17 & 0.71 & 20 & 8 & 0.40 & 32 & 21 & 0.66 & 76 & 46 & 0.61 \\
\hline May & 28 & 0 & - & 36 & 9 & 0.25 & 34 & 6 & 0.18 & 98 & 15 & 0.15 \\
\hline June & 26 & 2 & 0.08 & 36 & 0 & - & 40 & 3 & 0.08 & 102 & 5 & 0.05 \\
\hline July & 32 & 0 & - & 10 & 0 & - & 8 & 0 & - & 50 & 0 & - \\
\hline August & 2 & 0 & - & 36 & 0 & - & 34 & 0 & - & 72 & 0 & - \\
\hline September & 28 & 10 & 0.36 & 34 & 0 & - & 40 & 0 & - & 102 & 10 & 0.10 \\
\hline October & 22 & 24 & 1.09 & 26 & 13 & 0.50 & 32 & 7 & 0.22 & 80 & 44 & 0.55 \\
\hline November & 18 & 58 & 3.22 & 32 & 26 & 0.81 & 26 & 36 & 1.38 & 76 & 120 & 1.58 \\
\hline \multirow[t]{2}{*}{ December } & 22 & 25 & 1.14 & 26 & 14 & 0.54 & 30 & 39 & 1.30 & 78 & 78 & 1.00 \\
\hline & 290 & 261 & 0.90 & 310 & 144 & 0.46 & 354 & 288 & 0.81 & 954 & 693 & 0.73 \\
\hline P. BOQUERON & & & & & & & & & & & & \\
\hline January & & & & 5.2 & 0 & - & 10.4 & 2 & 0.19 & 15.6 & 2 & 0.16 \\
\hline February & & & & 2.6 & 1 & 0.38 & 2.6 & 0 & - & 5.2 & 1 & 0.19 \\
\hline March & & & & 2.6 & 0 & - & 10.4 & 2 & 0.19 & 13.0 & 2 & 0.15 \\
\hline April & & & & 2.6 & 0 & - & 18.2 & 3 & 0.16 & 20.8 & 3 & 0.14 \\
\hline May & & & & 10.4 & 3 & 0.29 & 20.8 & 1 & 0.05 & 31.2 & 4 & 0.13 \\
\hline June & 5.2 & 0 & - & 5.2 & 0 & - & 20.8 & 0 & - & 31.2 & 0 & - \\
\hline July & 5.2 & 0 & - & 5.2 & 0 & - & 23.4 & 0 & - & 33.8 & 0 & - \\
\hline August & 2.6 & 0 & - & 10.4 & 0 & - & 10.4 & 0 & - & 23.4 & 0 & - \\
\hline September & 2.6 & 0 & - & 10.4 & 0 & - & 18.2 & 0 & - & 31.2 & 0 & - \\
\hline October & 2.6 & 1 & 0.38 & 13 & 1 & 0.08 & 26.0 & 9 & 0.35 & 41.6 & 11 & 0.26 \\
\hline November & & & & 10.4 & 3 & 0.29 & 15.6 & 5 & 0.32 & 26.0 & 83 & 0.31 \\
\hline December & 5.2 & 0 & - & 10.4 & 0 & - & 20.8 & 8 & 0.38 & 36.4 & 8 & 0.22 \\
\hline & 23.4 & 1 & 0.04 & 88.4 & 8 & 0.09 & 197.6 & 30 & 0.15 & 309.4 & 39 & 0.13 \\
\hline JARDIN BOTANIC & & & & & & & & & & & & \\
\hline January & & & & 0.9 & 0 & - & 4.8 & 7 & 1.46 & 5.7 & 7 & 1.23 \\
\hline February & & & & 0.9 & 0 & - & 2.9 & 1 & 0.34 & 3.8 & 1 & 0.26 \\
\hline March & & & & 0.9 & 3 & 3.33 & 4.8 & 0 & - & 5.7 & 3 & 0.53 \\
\hline April & & & & 0.9 & 0 & - & 2.9 & 1 & 0.34 & 3.8 & 1 & 0.26 \\
\hline May & & & & 3.8 & 0 & - & 7.7 & 1 & 0.13 & 11.5 & 1 & 0.09 \\
\hline June & & & & 1.9 & 0 & - & 9.6 & 0 & - & 11.5 & 0 & - \\
\hline July & 0.9 & 0 & - & 2.9 & 0 & - & 7.7 & 0 & - & 11.5 & 0 & - \\
\hline August & 2.9 & 0 & - & 1.9 & 0 & - & 2.9 & 0 & - & 7.7 & 0 & - \\
\hline September & 1.8 & 1 & 0.56 & 3.8 & 0 & - & 5.8 & 1 & 0.17 & 11.4 & 2 & 0.18 \\
\hline October & 0.9 & 0 & - & 2.9 & 0 & - & 6.7 & 3 & 0.45 & 10.5 & 3 & 0.29 \\
\hline November & 0.9 & 0 & - & 1.9 & 0 & - & 5.8 & 6 & 1.03 & 8.6 & 6 & 0.70 \\
\hline December & 1.9 & 0 & - & 3.8 & 1 & 0.26 & 4.8 & 1 & 0.21 & 10.5 & 2 & 0.19 \\
\hline & 9.3 & 1 & 0.11 & 26.5 & 4 & 0.15 & 66.4 & 21 & 0.32 & 102.2 & 26 & 0.25 \\
\hline CAMPOSOTO & & & & & & & & & & & & \\
\hline January & & & & & & & 7.2 & 18 & 2.50 & 7.2 & 18 & 2.50 \\
\hline February & & & & & & & 6.5 & 8 & 1.23 & 6.5 & 8 & 1.23 \\
\hline March & & & & & & & 7.9 & 0 & - & 7.9 & 0 & - \\
\hline April & & & & & & & 8.6 & 0 & - & 8.6 & 0 & - \\
\hline May & & & & & & & 11.5 & 0 & - & 11.5 & 0 & - \\
\hline June & & & & & & & 12.9 & 0 & - & 12.9 & 0 & - \\
\hline July & & & & & & & 8.6 & 0 & - & 8.6 & 0 & - \\
\hline August & & & & & & & 2.9 & 0 & - & 2.9 & 0 & - \\
\hline September & & & & & & & 6.5 & 0 & - & 6.5 & 0 & - \\
\hline October & & & & & & & 13.7 & 8 & 0.58 & 13.7 & 8 & 0.58 \\
\hline November & & & & 0.7 & 0 & - & 6.5 & 5 & 0.77 & 7.2 & 5 & 0.69 \\
\hline December & & & & 9.3 & 8 & 0.86 & 6.5 & 4 & 0.62 & 15.8 & 12 & 0.75 \\
\hline & & & & 10.0 & 8 & 0.80 & 99.3 & 43 & 0.43 & 109.3 & 51 & 0.47 \\
\hline $\begin{array}{c}\text { HUERTO ANIMA } \\
\text { Month }\end{array}$ & & & & & & & & & & & & \\
\hline January & & & & 0.5 & 1 & 2.00 & & & & 0.5 & 1 & 2.00 \\
\hline February & & & & 0.5 & 0 & - & & & & 0.5 & 0 & - \\
\hline March & & & & 0.5 & 5 & 10.0 & & & & 0.5 & 5 & 10.0 \\
\hline April & & & & 0.5 & 1 & 2.00 & & & & 0.5 & 1 & 2.00 \\
\hline May & & & & 1.1 & 0 & - & & & & 1.1 & 0 & - \\
\hline June & & & & 1.1 & 0 & - & & & & 1.1 & 0 & - \\
\hline July & 4 & 0 & - & 1.1 & 0 & - & & & & 5.1 & 0 & - \\
\hline August & 1.7 & 0 & - & 2.8 & 0 & - & & & & 4.5 & 0 & - \\
\hline September & 1.7 & 3 & 1.76 & 1.1 & 0 & - & & & & 2.8 & 3 & 1.07 \\
\hline October & 1.1 & 0 & - & 2.8 & 1 & 0.36 & & & & 3.9 & 1 & 0.26 \\
\hline November & 0.5 & 5 & 10.0 & 1.8 & 1 & 0.56 & & & & 2.3 & 6 & 2.61 \\
\hline December & 0.5 & 0 & - & 1.1 & 0 & - & & & & 1.6 & 0 & - \\
\hline & 9.5 & 8 & 0.84 & 14.9 & 9 & 0.60 & & & & 24.4 & 17 & 0.79 \\
\hline
\end{tabular}

